\title{
Weekend courses on ultrasonography as a form of teaching knowledge and the skills necessary to perform ultrasounds in the family physician's practice
}

KATARZYNA SZWAMEL ${ }^{1,2, c-F}$, PIOTR POLAŃSKI ${ }^{3, \text { A-E }}$, DONATA KURPAS ${ }^{1,2, ~ A-E}$

${ }^{1}$ Opole Medical School, Poland

${ }^{2}$ Department of Family Medicine, Wroclaw Medical University, Poland

${ }^{3}$ Family Physician Practice, Non-Public Healthcare Center, Mieroszow, Poland

A - Study Design, B - Data Collection, C - Statistical Analysis, D - Data Interpretation, E - Manuscript Preparation, F - Literature Search, G - Funds Collection

Summary Background. Growth in ultrasound use by non-radiologists has outpaced radiologist-performed ultrasound in the last decade. Poland has a well-organized system of teaching ultrasonography.

Objectives. To establish whether family physicians, after completion of weekend courses on ultrasound abdominal cavity imaging, recommend this form of training. To identify main reasons for family physician to attend training in USG, their preferences regarding the form of such courses and the difficulties most often faced by family physicians when performing a USG.

Material and methods. This survey-based study using the authors' own questionnaire was conducted in March 2016 among 81 primary care physicians who had completed weekend courses on ultrasound abdominal cavity imaging.

Results. The main reasons why family physicians participated in ultrasound courses were the possibility of expanding knowledge (50.7\%) and quicker patient diagnosis (20\%). According to the respondents, difficulties with performing an ultrasound resulted mainly from their insufficient knowledge of anatomy $(41.30 \%)$, technical problems $(32.61 \%)$ and a lack of spatial imagination $(28.26 \%)$. Organs that family physicians found especially difficult to diagnose were the retroperitoneal space $(40 \%)$ and pancreas (36\%). The majority of participants (86.36\%) would recommend weekend ultrasound courses.

Conclusions. Family physicians participate in ultrasound courses mostly for economic reasons. Intensive weekend training is enough to gain the knowledge necessary to perform an ultrasound examination. A crucial element of physicians' ultrasound education is two week's work on a provided ultrasound scanner in a primary care center. More time should be devoted to teaching a USG examination of the retroperitoneal space and the pancreas, as well as spatial imagination training.

Key words: family physicians, ultrasonography, primary health care, medical education.

Szwamel K, Polański P, Kurpas D. Weekend courses on ultrasonography as a form of teaching knowledge and the skills necessary to perform ultrasounds in the family physician's practice. Fam Med Prim Care Rev 2017; 19(3): 270-276, doi: https://doi.org/10.5114/ fmpcr.2017.69290.

\section{Background}

The presence of an ultrasound (USG) scanner can have positive effects on the outcomes and case management in general practice [1]. Growth in USG use by non-radiologists has outpaced radiologist-performed USG in the last decade, and the trend is sure to continue with increased education and the accessibility of portable USG devices [2]. With the widespread agreement that a bedside USG can increase patient safety, reduce costs and guide management in real time, there is now a growing push for physicians to be exposed to systematic USG training [3].

Examination results and further diagnosis of patients depend on the professionalism of the USG operators, their qualifications and experience $[4,5]$. The Royal College of Radiologists in the UK gives advice on USG training, stating "operators are ethically and legally vulnerable if they have not been adequately trained" [6].

There are different forms and durations of USG courses for medical students and family physicians. It is possible to train residents and medical students using 5 to 20 hours of focused USG training courses to perform various narrowly defined tasks $[7,8]$. Wong et al. described a hand-carried USG training session that was organized for faculty members from the Medical College of Wisconsin's Department of Family and Community Med- icine. An 8-hour training course consisting of didactic lectures, case reviews and hands-on learning experience with imaging on standardized patients. The objective of the course was to introduce family medicine physicians to focused USG acquisition and interpretation of the gall bladder, kidney, heart and abdominal aorta [7].

Suramo et al. investigated the effectiveness of a training program of "limited goal-oriented abdominal sonography" for general practitioners (GPs). The authors indicated that after one month of intensive training (about 100 examinations), four test subjects succeeded in technically performing examinations in four out of five patients and were able to rule out or exclude fluid collections, aortic aneurysms and common gallbladder disease [9].

The results of the study by Esquerrà et al. demonstrate the feasibility of the performance, by trained GPs, of USG examinations of low complexity of the abdomen with diagnostic competence. After six month, an "ad interim" analysis showed a kappa index of 0.85 for the primary USG diagnosis. At the end of the study, an overall kappa index of 0.89 (95\% Cl: 0.82-0.98) was achieved [10].

Courses for family physicians are expected to improve their skills in interpreting USG scans for the most frequent diseases $[11,12]$. According to Jakubowski, during a 12-month education 
period, one can acquire the ability to perform a USG examination. The author emphasizes the significance of regular training, the use of appropriate USG scanners and the necessity of learning under the direction of professional staff [12]. However lengthy medical school USG training may not be the best choice for busy family physicians due to time.

At present, Poland has a well-organized, family physician-oriented system of teaching ultrasonography [13]. What is becoming more and more popular is the organization of commercial several-day courses on USG, during which physicians can learn to perform, for example, a USG of the abdominal cavity at a basic level. Such courses usually last from 2 to 5 days, and upon their completion, the participants can obtain from 15 [14] to 40 credit points and, additionally, points from the Polish Ultrasound Society [15]. The prices of these courses usually range from 1,200 to 2,500 PLN (277.60-578.34 EUR, according to the average exchange rate of the Polish National Bank dated 02.20.2017, 1 EUR = 4.3227 PLN) [14-18]; however, cheaper offers can also be found (599 PLN = 138.57 EUR) [19]. The points and skills acquired during such courses are confirmed by a certificate of completion [14-18], as recommended by the Polish Ultrasound Society and the Polish Medical Society of Radiology [20].

According to the Polish Ultrasound Society, each physician - irrespective of what specialist course he/she has completed or is in the middle of - can pursue USG certificates in the field of general USG or specific fields (Doppler USG of neck and spinal vessels, echocardiography in adults, USG of motor organs, bony face and blood vessels, as well as USG in obstetrics, gynecology, ophthalmology, urology and pediatrics) [21].

The Polish Gynecological Society - Ultrasound Section keeps a register of certificates issued [22]. A similar register will soon be placed on the website of the Polish Society of Rheumatology [23]. Unfortunately, an analysis of the available data shows that we lack statistics concerning the number of family physicians with certificates entitling them to perform USG examinations, as well as the number of USG scanners in family physician practices. There are still too few reports on family physicians' motivation to participate in USG courses, their preferences for the form of such courses and opinions about their quality.

\section{Objectives}

To establish whether family physicians who have completed the weekend course on USG imaging of the abdominal cavity, entitled "Ultrasound imaging in family medicine: the Lower-Silesian school", would recommend such a form of training to family physicians in the future. The specific objectives of the study were: to identify the main reasons that cause family physicians to attend training in USG, their preferences regarding the form of such courses and the difficulties most often faced by family physicians when performing a USG.

\section{Material and methods}

The study was performed in March 2016 and involved 81 primary health physicians who had completed a weekend course entitled "Ultrasound imaging in family medicine: the Lower-Silesian school", organized by the Innovative Medicine Cluster, Wroclaw, in 2014-2016. The research was conducted in accordance with the Declaration of Helsinki and was approved by the Bioethical Commission of the Medical University in Wroclaw (approval no. KB-422/2014).

Before the study, each participant was informed of its purpose and the expected benefits. The respondents, who only provided the numbers of their National Health Fund contracts and no personal data, were guaranteed anonymity and the freedom to take part and withdraw at any stage.

\section{Participants}

Our study involved 81 subjects, including 52 females (65\%) and 28 males (35\%) (1: no data), with a median age of 51 years (min-max: $28-70$ years) and 18 years work experience (min-max: 1-47 years). The criteria of inclusion to the study were: being a family physician and having completed the weekend course entitled "Ultrasound imaging in family medicine: the Lower-Silesian school". The return of the completed online questionnaire was regarded as the respondent's consent to take part in the study.

The majority of participants had completed specialist courses in family medicine $(59 / 67 ; 88.06 \%)$. Others had specialties in internal medicine $(26 / 67 ; 33.81 \%)$, pediatrics $(17 / 67 ; 25.37 \%)$ and other branches of medical practice $(8 / 67 ; 11.94 \%)$. Some of the respondents $(17 / 67 ; 24.64 \%)$ were in the middle of a second specialist course in family medicine, palliative care, pediatrics or general surgery. The respondents were mainly employed in urban primary care centers $(41 / 80 ; 51.25 \%)$ and in centers providing services for residents of both cities and rural areas (23/80; $28.75 \%)$. Only 16 respondents $(20 \%)$ worked in a family physician practice in purely rural areas. Most family physicians worked in a team $(64 / 81 ; 79.01 \%)$. The participants in the course were mostly the owners of the practice they worked in $(36 / 64 ; 56.25 \%)$, but there were also employees without their own lists of patients $(12 / 64 ; 18.75 \%)$, resident physicians $(12 / 64 ; 18.75 \%)$ and contract workers $(4 / 64 ; 6.25 \%)$. Descriptive statistics of quantitative variables characterizing each group of physicians in the study are shown in Table 1.

\section{Ultrasound course description}

The USG course for screening purposes was designed for family physicians with many years of experience running their practices and who were interested in acquiring the practical

\begin{tabular}{|l|l|l|l|l|l|l|l|l|}
\hline \multicolumn{6}{|c|}{ Table 1. Descriptive statistics of the study sample (none of the variables had normal distribution according to the Shapiro-Wilk test) } \\
\hline Variable & $n$ & median & $\mathbf{Q} .25 \%$ & $\mathbf{Q} .50 \%$ & $\mathbf{Q} .75 \%$ & $\min$ & $\max$ \\
\hline Age & 80 & 51.0 & 43.0 & 51.0 & 55.3 & 28.0 & 70.0 \\
\hline Years worked in primary care & 80 & 18.0 & 12.0 & 18.0 & 26.3 & 1.0 & 47.0 \\
\hline $\begin{array}{l}\text { Size of the population under the care of the } \\
\text { family physician's practice }\end{array}$ & 68 & $3,075.0$ & $2,200.0$ & $3,075.0$ & $4,387.5$ & $1,235.0$ & $9,999.0$ \\
\hline $\begin{array}{l}\text { Total number of physicians in the family } \\
\text { physician's practice }\end{array}$ & 59 & 4.0 & 3.0 & 4.0 & 6.0 & 2.0 & 10.0 \\
\hline $\begin{array}{l}\text { Number of primary health physicians able } \\
\text { to perform a USG in the family physician's } \\
\text { practice }\end{array}$ & 62 & 2.0 & 1.0 & 2.0 & 3.0 & 0.0 & 7.0 \\
\hline $\begin{array}{l}\text { Number of USG scans performed in the fam- } \\
\text { ily physician's practice per week }\end{array}$ & 47 & 5.0 & 4.0 & 5.0 & 10.0 & 1.0 & 25.0 \\
\hline $\begin{array}{l}\text { Average number of hours spent on perform- } \\
\text { ing a USG per week }\end{array}$ & 49 & 3.0 & 2.0 & 3.0 & 5.0 & 1.0 & 12.0 \\
\hline
\end{tabular}




\begin{tabular}{|c|c|}
\hline First day (a) & Duration (in minutes) \\
\hline Introduction & 15 \\
\hline $\begin{array}{l}\text { Ultrasonographic anatomy, anatomy of the abdominal cavity, correct description of a USG examination, nu- } \\
\text { ances of USG nomenclature, model descriptions (with summarizations) of the most common pathologies, } \\
\text { measurements, techniques applied to obtain a correct USG scan - lecture }\end{array}$ & 45 \\
\hline $\begin{array}{l}\text { Practical training - the participants examine each other - USG anatomy - the participants learn to perform } \\
\text { a USG of the abdominal cavity. The participants work on their own to improve the technique of USG imag- } \\
\text { ing }\end{array}$ & 60 \\
\hline The liver, bile duct, gall bladder - lecture & 45 \\
\hline $\begin{array}{l}\text { Practical training - the participants examine each other - they assess the bile duct and liver - they learn to } \\
\text { perform a USG of the abdominal cavity. The participants learn to prepare a description of a USG examina- } \\
\text { tion }\end{array}$ & 90 \\
\hline Anatomy of the pancreas - lecture & 45 \\
\hline $\begin{array}{l}\text { Anatomy of the kidneys, adrenal glands, retroperitoneal space (abdominal cavity vessels, retroperitoneal } \\
\text { lymph glands) - lecture }\end{array}$ & 45 \\
\hline The pelvic organs (bladder, reproductive organs, prostate) - lecture & 45 \\
\hline Practical training - USG of the pancreas, kidneys and retroperitoneal space & 45 \\
\hline Practical training - USG of the pelvic organs & 60 \\
\hline Duration of learning on the first day (a) & 495 minutes $=11$ hours \\
\hline \multicolumn{2}{|l|}{ Second day (b) } \\
\hline $\begin{array}{l}\text { Examination of patients with pathologies within the abdominal cavity (previously diagnosed by the orga- } \\
\text { nizer) }-4 \times 90 \text {-minute training series }\end{array}$ & $4 \times 90$ minutes \\
\hline Duration of learning on the second day (b) & 360 minutes $=8$ hours \\
\hline $\begin{array}{l}\text { The participants are recommended to perform a USG examination using the provided scanner in their fam- } \\
\text { ily physician practices every day for two weeks. As homework, they are obliged to prepare at least } 3 \text { USG } \\
\text { scans of their patients, with descriptions recorded on a pen drive (c) }\end{array}$ & $\begin{array}{l}2 \text { teaching hours ( } 90 \\
\text { minutes) per day }\end{array}$ \\
\hline Duration of learning using the USG scanner provided by a technological partner (c) & $\begin{array}{l}90 \text { minutes per day } x \\
10 \text { working days })=900 \\
\text { minutes }=20 \text { hours }\end{array}$ \\
\hline \multicolumn{2}{|l|}{ Third day (d) } \\
\hline Opening of the meeting, summarization of the physicians' own work and experiences from the program & 15 \\
\hline Seminar - the participants present their cases - approx. 10 minutes for each participant & 120 \\
\hline Lecture - USG of the digestive tract. Basic pathological symptoms from the chest & 45 \\
\hline $\begin{array}{l}\text { Lecture "USG scanner - the possibility of advanced adjustment, personalization and other technical } \\
\text { aspects" }\end{array}$ & 45 \\
\hline Duration of learning on the third day (d) & 225 minutes $=5$ hours \\
\hline TOTAL $a+b+c+d$ & 44 hours \\
\hline
\end{tabular}

skills needed to perform USG imaging of the abdominal cavity organs. It was intended as a weekend workshop with instructions given by an experienced radiologist, along with training with USG scanners in groups of two under the watchful eye of an assistant. The priority of the course was to give the participants practical training and to teach them the methodology and techniques of USG imaging of the abdominal cavity organs for screening purposes.

The course on USG imaging of the abdominal cavity organs, organized by the Innovative Medicine Cluster, consisted of 44 teaching hours (45-minute classes). Lectures were given in small, twelve-person groups, and practical training was given in pairs (each pair trained on a separate USG scanner). A detailed program of the course is shown in Table 2.

For two weeks following the course, the physicians were provided with USG scanners for use in their own practices. After one month, recapitulation meetings were held as a part of the knowledge evaluation stage. The participants were asked to present the results of at least three of the most interesting cases they encountered in the form of scans with descriptions. The final (evaluation) stage of the course involved an analysis of the material, combined with critical comments and assessment from the facilitator, an evaluation and summing up seminar and an acquired knowledge test.
The exam consisted of two parts: the practical and the written test. The practical part was evaluated by a case study of at least three patients in terms of the ultrasonographic nomenclature and correct imaging of the organs by pictures and video. The written test consisted of a series of 10 ultrasound images and multiple-choice questions assessing knowledge acquisition.

Passing exam was necessary to obtain the training points of the Standing Committees of the Supreme Medical Council. The condition for obtaining a positive grade from the course was to provide correct answers to $2 / 3(66 \%)$ of the questions. The vast majority of students had no problems with this.

\section{Study questionnaire}

In our study, a diagnostic survey-based method was employed. After the course, the physicians completed an online questionnaire of our devising. The questionnaire consisted of 77 questions; in the current paper, 24 of the questions were analyzed. In the previous paper, 53 of the questions were analyzed. The purpose of this study was to determine which ultrasound scans are most often performed in the practices of family physicians, as well as what factors determine whether ultrasound scans are performed [24]. 
The participants completed an online questionnaire, including mainly queries on whether the form of teaching (intensive weekend courses) was sufficient to acquire the knowledge and skills necessary to perform USGs, and whether after such a course, family physicians would be prone to make their USG scanners available to another family medicine resident physician in the future. The respondents were also asked to indicate the sources of financing for the USG course and scanners, to subjectively assess the effectiveness of work on the provided USG scanner and to state what difficulties they faced when performing USG imaging. Additionally, they were asked about their motivation to participate in weekend courses in the form proposed by the Innovative Medicine Cluster, as well as their preferences for future USG training.

The method of competent judges was applied: five family physicians completed the questionnaire as a part of the pilot study; ambiguous and doubled queries were corrected at this stage.

\section{Statistical analysis}

In the study, mostly qualitative variables were used, for which the number and the percentage were given. None of the quantitative variables had normal distribution, which was verified by the Shapiro-Wilk test. Therefore, in the description of these variables, the median, minimum and maximum values were given each time.

R 3.1.3 (for Mac OS X 10.11.5) statistical software was used for all analyses. The critical level of significance was set at 0.05 .

\section{Results}

\section{Motivation to take part in USG courses}

For the majority of the participants $(50 / 72 ; 69.44 \%)$, a USG course in family medicine was the first serious contact with USG. Only 22 individuals (30.56\%) had previously participated in USG courses before. The most important reasons for taking part in a USG course given by the family physicians were: the possibility of expanding knowledge $(38 / 75 ; 50.7 \%)$, quicker diagnosis of patients $(15 / 75 ; 20 \%)$, a wish to fulfill a longstanding desire to perform USG scanning $(8 / 75 ; 10.7 \%)$, fighting against job burnout $(6 / 75 ; 8 \%)$, searching for a new passion $(4 / 75 ; 5.3 \%)$, extending the array of services $(2 / 75 ; 2.7 \%)$, counting on financial benefit $(1 / 75 ; 1.3 \%)$ and gaining prestige in the eyes of patients $(1 / 75 ; 1.3 \%)$.

The course "USG imaging in family medicine" was financed mainly from the respondents' own resources (38/65; 58.46\%), as well as from so-called "other financial resources" (16/65; $24.62 \%)$. Employers paid for the training of 11 physicians $(11 / 65 ; 16.92 \%)$.

\section{Imaging problems}

According to the respondents, the difficulties they faced during USG examinations resulted mainly from their inadequate knowledge of anatomy $(19 / 46 ; 41.3 \%)$, technical problems (15/46; 32.61\%), a lack of spatial imagination (13/46; 28.26\%), lack of time $(11 / 46 ; 23.91 \%)$, no funds for buying a USG scanner $(8 / 46 ; 17.39 \%)$ and lack of interest in USG courses $(4 / 46 ; 8.7 \%)$.

Organs that family physicians found especially difficult to diagnose are the retroperitoneal space $(20 / 50 ; 40 \%)$ and the pancreas $(18 / 5 ; 36 \%)$ (Figure 1$)$.

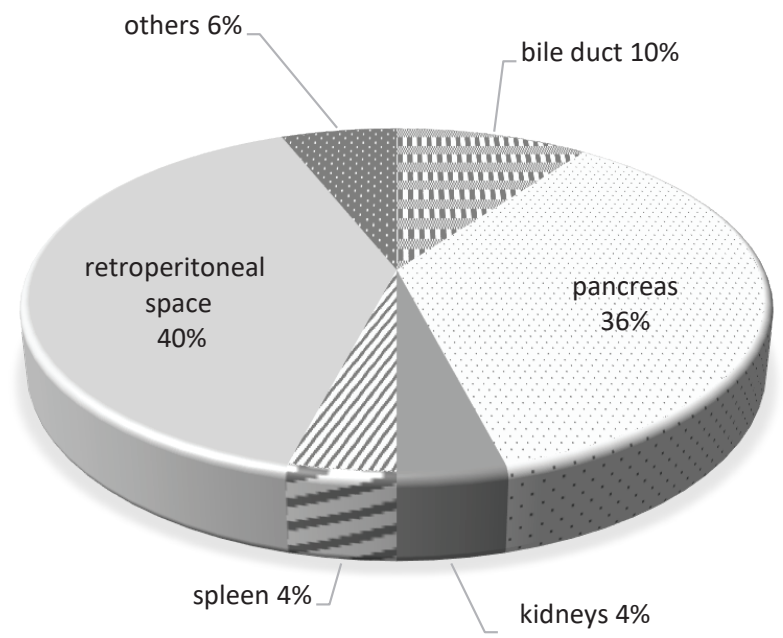

Figure 1. Organs regarded as especially difficult to diagnose

\section{Purchase of a USG scanner}

As part of the program, the participants of the course could buy a USG scanner from the program's technological partner - GE Healthcare - at a very preferential price. Models that enjoyed the greatest popularity were the Logiq F6 (18/44; 40.91\%) and the Logiq V5 $(12 / 44 ; 27.27 \%)$. Nine of the respondents $(9 / 44 ; 20.45 \%)$ bought a scanner outside the program, and five respondents $(5 / 44 ; 11.36 \%)$ said that they still did not have USG scanners. The majority of those who bought USG scanners would recommend their models to other physicians (42/43; 97.67\%). The majority of the buyers $(29 / 40 ; 72.50 \%)$ also claimed that the purchase of a scanner was not a heavy financial burden for the family physician's practice. Some family physicians (19/39; $48.72 \%$ ) took out a bank loan to buy the scanners, and $30 \%$ $(12 / 40)$ paid for them using the financial product offered by EFL Finance.

A few family physicians $(6 / 40 ; 15 \%)$ considered buying an additional probe for the USG scanner on the basis of cooperation with other specialists. $18.92 \%$ (7/37) of family physicians were interested in buying more advanced equipment in the future to enhance their further development, and $43.24 \%$ (14/37) would consider such a possibility only if there was an EU investment program or other external funding. No one (40/40; $100 \%)$ regretted the purchase of a USG scanner.

$60.42 \%(29 / 48)$ of the physicians would make their scanners available to other family medicine residents, so that they could use them and achieve proficiency after the completion of a USG course.

\section{Preferences for the form of courses}

Most participants (51/70; 72.86\%) claimed that the form of teaching (intensive weekend courses) was sufficient for them to gain the necessary knowledge and to start performing USG examinations on their own. Problems with the assimilation of new material were primarily caused by insufficient time for exercises $(10 / 18 ; 55.56 \%)$ and the practical part $(7 / 18 ; 38.89 \%)$. Work in the primary care center on a scanner provided as part of the course was effective according to most participants (49/65; 75.38\%), while $6.15 \%(10 / 65)$ admitted they did not have enough time to perform USG examinations in that period.

The form of seminars, with evaluation of the previously prepared cases presented one month after the completion of 
the course, seemed constructive and helpful, as it let the family physicians dispel their doubts $(45 / 65 ; 69.23 \%)$ and consult USG scans with a specialist $(45 / 65 ; 69.23 \%)$.

Weekend USG courses would be recommended by 57 participants (57/66; 86.36\%). The answer "I would recommend it, but I would change something" was given by 9 respondents (9/66; 13.64\%). There was not a single person who would not recommend this type of course. A vast majority of the participants $(66 / 69 ; 95.65 \%)$ would like to take part in further meetings. The forms of the course regarded by the respondents as the most convenient were cyclic meetings in the family physician's practice $(51 / 63 ; 80.95 \%)$ and cyclic online courses $(32 / 63$; $50.79 \%)$. The most desirable frequency of meetings would be once per quarter of a year $(34 / 63 ; 53.97 \%)$, once a month $(16 / 63 ; 25.40 \%)$, once per half of a year $(9 / 63 ; 14.29 \%)$ and once a year $(3 / 63 ; 4.76 \%)$.

The majority of the respondents $(51 / 63 ; 80.95 \%)$ would be inclined to prepare "interesting cases" for such meetings. A group of 10 individuals would be glad to listen to the experiences of other participants, but would not be able to prepare their own cases due to insufficient spare time. 56.06\% (37/66) of the participants would like to consult "doubtful images" online with other family physicians, specialists or radiologists, $28.79 \%(19 / 66)$ believed that this role could be fulfilled by workshops and online courses, and $12.12 \%(8 / 66)$ would rather refer their patients to a radiologist in case of any doubts to confirm or deny their results.

The majority of family physicians $(66 / 69 ; 95.65 \%)$ plan to improve their skills in the field of USG during subsequent courses. The most desirable courses are those on USG imaging of the carotids $(39 / 63 ; 61.90 \%)$, the neck (evaluation of the thyroid gland, lymph and salivary glands) $(37 / 63 ; 58.73 \%)$, USG examination of children (34/63; 53.97\%), USG in oncology (34/63; $53.97 \%)$, an extended course on USG of the alimentary canal $(32 / 63 ; 50.79 \%)$ and USG of the knee joint $(29 / 63 ; 46.03 \%)$.

\section{Discussion}

The technology continues to improve, and an increasing number of primary care physicians have experience and clinical skills to utilize USG [25].

Our study presents various reasons that encouraged family physicians to take part in USG courses, but only a small portion mentioned the financial aspect. Sowińska-Neuman maintains that performing USG scans by family physicians is an optimal way of screening. The author emphasizes the financial aspect as the one which should particularly motivate physicians to participate in a course. She also reported that when performing 369 USG scans for specific indications over 18 months, she saved 9,225 PLN, which, in another case, could have been spent on USG imaging in other centers (the assumed price for one USG was 25 PLN) [13].

\section{Imaging problems}

In this study, we demonstrated that the organs which family physicians found especially difficult to diagnose by USG imaging were the retroperitoneal space and the pancreas. Ćwik points out that the main factor hindering USG diagnosis of the pancreas is gas accumulating in the alimentary canal. To improve the conditions under which an examination is performed, patients should avoid bloating and indigestible food for two days prior to USG, and the examination should be performed in the morning on an empty stomach. It is even recommended to take pharmacological agents to reduce the volume of gas in the alimentary canal [26]. Unfortunately, the quality of patients' preparation was not assessed within our study.

In our study, physicians reported difficulties with performing a USG, which in their opinions resulted mainly from inadequate knowledge of anatomy, technical problems and a lack of spatial imagination. Wong et al. claims that sonographic images require knowledge of USG physics for accurate image acquisition, which in turn must be appropriately interpreted and then correctly applied to the clinical scenario at hand [7]. It is recommended that when enrolling in the course, participants should be informed about the necessity of revising their knowledge of anatomy of the part of the body which is to be examined during the course, e.g. the anatomy of the abdominal cavity organs, as well as preparing patients for an examination. Moreover, Tshibwabwa and Groves indicated that small-group, problembased USG anatomy sessions for students, which focuses on small-group, problem-based active learning, are a highly effective method for facilitating student learning and significantly enhance the knowledge of clinical anatomy [27]. The organizers of the course described in our study planned the sizes of groups quite well, as the lectures were given in small, twelve-person groups, and practical training was carried out in pairs.

\section{Opinions about weekend courses vs preferences of the participants}

The majority of the physicians held the opinion that an intensive weekend course on USG imaging was a sufficient form of obtaining the necessary knowledge and they were able to start performing USG scans on their own. They stated that they would absolutely recommend this form of training to those interested in USG. The results confirming that the majority of GPS would make their USG scanners available to other family medicine residents after a USG course in order to help them improve their skills is proof of the confidence in the quality of training and care for both methodology and safe operation of the equipment. It should be underlined as well that only half of the participants were owners of the practices they worked in (only this group had USG scanners at their disposal).

The participants asserted that too little time was devoted to exercises and practical training. In the study by Latalski et al., GPs also believed that courses should mainly provide practical training and should be run by qualified ultrasonographers with teaching experience [11]. In our study, most physicians assessed working in their own primary care centers, using USG scanners provided as a part of the course, as effective. Sowińska-Nueman concluded that a comparison of USG results with final diagnoses is a vital element of learning USG. GPs have this possibility, because patients with their diagnoses return to them after consultation or specialist treatment, which is an optimal situation [13].

In our study, the majority of physicians would like to consult online doubtful images with other GPs, other specialists or radiologists. This result corresponds with the findings reported by Latalski et al., who demonstrated that GPs perceive their knowledge and skills as inadequate, and thus they often need help from more experienced colleagues [11]. Persistent barriers to the deployment of telesonography systems include a lack of telecommunications access, a lack of standard training and operational protocols and a scarcity of research regarding the long-term health impact of telesonography within target communities [28]. To enable family physicians to consult online, it is necessary to develop a teleinformatic infrastructure for the entire health care system. Unfortunately, a report on coordinated health care shows that information technology in the Polish health care system is still poorly developed and lacks regulations as well as the motivation of various health care centers to become involved in computer-based integration [29].

As a convenient form of learning USG, the participants mentioned cyclic online courses, in which they could take part using their own computers. Brisson et al. assert that telemedic solutions can prove useful in learning certain USG imaging skills [30]. Turner et al. also demonstrated the high effectiveness of USG programs consisting of e-learning paired with expert-led, hands-on training [3]. 
In turn, Micks noted that in 2014, the Faculty of Medicine of Memorial University (Canada) conducted training in the U.S. for rural family doctors, consisting of online lectures introducing basic skills and concepts, followed by 1.5 days of competency development. Specific skills included focused assessment with sonography for trauma, early pregnancy assessment, detection of abdominal aortic aneurysm and limited cardiac echocardiography. At the end of the course, family medicine residents had completed on average 10 to 15 supervised scans before moving to their rural placements to work on their competency training [31].

\section{Cost and quality of USG scanners}

According to Genc et al., a USG scanner is an element that, apart from the knowledge and skills of the physician, relates to the value of USG examinations [4]. Gajewicz concluded that buyers should use the guidelines of the Polish USG Society when choosing a USG scanner, as both the class and age of the equipment determine the quality of the USG image [20]. An average quality scanner is more than adequate for the needs of a family physician's practice [4]. As a part of the program, participants of the course could buy a USG scanner from the program's technological partner at a very preferential price $(50-60,000$ PLN, depending on the model; $11,566-13,880$ EUR, according to the average exchange rate of the Polish National Bank dated 02.20.2017, 1 EUR = 4.3227 PLN). Nowadays, the buying of a USG scanner is easy, as the price is not a financial barrier, and performing USG scans should allow for the possibility to pay off the scanner within three years of its operation [13]. In our study, most participants did not regard the purchase of a USG scanner as a heavy financial burden for a family physician's practice.

\section{Limitations of the study}

A significant limitation is the number of subjects and lack of comparison with courses of varying structures. Furthermore, to learn the reasons for non-participation, a further step should be to interview GPs who have not participated in USG courses.

\section{Conclusions}

Motivation of family physicians to take part in USG courses was mostly non-economic. Intensive weekend training is enough to gain the necessary knowledge and start performing USG examinations. More time should be devoted to teaching a USG examination of the retroperitoneal space and the pancreas, as well as spatial imagination training. One of the crucial elements of family physicians' USG education is two week's work on a USG scanner that would be provided in their own primary care centers. It is necessary to organize further courses to improve physicians' practical skills in performing USG examinations. In prospective analyses, an interview with GPs who have not participated in USG courses should be included.

Acknowledgements. The authors would like to thank Dr. Ewa Nienartowicz and the family physicians involved in the research (Katarzyna Trybucka, Lucyna Polańska, Barbara Dybek, Agata Sławin, Paweł Brzozowski, Jan Duda, Zbigniew Tyszkowski, Anna Krzyszowska-Kamińska, and Piotr Stankiewicz) for their factual suggestions.

Source of funding: This work was supported by funds allocated to the statutory activities of the Department of Family Medicine, Medical University in Wroclaw.

Conflict of interest: The authors declare no conflict of interests.

\section{References}

1. Bono F, Campanini A. The METIS project for generalist ultrasonography. J Ultrasound 2007; 10(4): 168-174, doi: 10.1016/j. jus.2007.09.003.

2. Levin DC, Rao VM, Parker L, et al. Noncardiac point-of-care ultrasound by nonradiologist physicians: how widespread is it? J Am Coll Radiol 2011; 8(11): 772-775.

3. Turner EE, Fox JC, Rosen M, et al. Implementation and assessment of a curriculum for bedside ultrasound training. J Ultrasound Med 2015; 34(5): 823-828, doi: 10.7863/ultra.34.5.823

4. Genc A, Ryk M, Suwała M, et al. Ultrasound imaging in the general practitioner's office - a literature review. J Ultrason 2016; 16(64): 78-86, doi: 10.15557/JoU.2016.0008.

5. Bień S. The importance of General Practitioner in diagnosis and treatment of a mass in the neck. Probl Med Rodz 2012; 14(3): 49-55.

6. Bodenham AR. Editorial II: ultrasound imaging by anaesthetists: training and accreditation issues. Br J Anaesth 2006; 96(4): 414e7.

7. Wong F, Franco Z, Phelan MB, et al. Development of a pilot family medicine hand-carried ultrasound course. WMJ 2013; 112(6): 257-261.

8. Bornemann P, Johnson J, Tiglao S, et al. Assessment of Primary Care Physicians' Use of a pocket ultrasound device to measure left ventricular mass in patients with hypertension. J Am Board Fam Med 2015; 28(6): 706-712, doi: 10.3122/jabfm.2015.06.140314.

9. Suramo I, Merikanto J, Päivänsalo M, et al. General practitioner's skills to perform limited goal-oriented abdominal US examinations after one month of intensive training. Eur J Ultrasound 2002; 15(3): 133-138.

10. Esquerrà $\mathrm{M}$, Roura Poch $\mathrm{P}$, Masat Ticó $\mathrm{T}$, et al. Abdominal ultrasound: a diagnostic tool within the reach of general practitioners. Aten Primaria 2012; 44(10): 576-583, doi: 10.1016/j.aprim.2011.07.016.

11. Latalski M, Woźnica I, Bełtowska K. Badania ultrasonograficzne w podstawowej opiece zdrowotnej - możliwości realizacji i potrzeby szkoleniowe lekarzy. Ultrasonografia 2000; 4: 47-52 (in Polish).

12. Jakubowski W. Profesjonalna ultrasonografia w gabinecie lekarza rodzinnego. Gabinet Prywatny 2005; 1: $35-38$ (in Polish).

13. Sowińska-Neuman L. Umiejętność samodzielnego wykonywania badań ultrasonograficznych w praktyce lekarza rodzinnego. Ultrasonografia 2009; 38: 51-54 (in Polish).

14. Podstawowy kurs USG. Medycyna Praktyczna [cited: 21.11 .2016 ]. Available from URL: http://szkolenia.mp.pl/szkolenia/show?id=206 (in Polish).

15. CEDUS. Centrum Diagnostyki Obrazowej. Szkolenia dla lekarzy. Kursy USG [cited: 21.11.2016]. Available from URL: http://www.cedus. edu.pl/typkursu/64/kursy usg.html (in Polish).

16. Roztoczańska Szkoła Ultrasonografii [cited: 21.11.2016]. Available from URL: https://www.usg.com.pl/kursy/996/0/2/\#kurs996 (in Polish).

17. USG w Medycynie Rodzinnej. Klaster Innowacyjna Medycyna [cited: 21.11.2016]. Available from URL http://robieusg.pl/akcja-promocyjna-aparat-z-kursami/ (in Polish).

18. Wielkopolska Szkoła Diagnostyki Obrazowej [cited: 21.11.2016]. Available from URL http://www.obraz.pl/p/pl/239/ultrasonografia+jamy+brzusznej+-+dr+krzysztof+kaczmarek-+dr+piotr+stajgis++8211+1-4+czerwca+2017+-+brodnica+sremska.html (in Polish).

19. Profimedical. Szkoła USG [cited: 21.11.2016]. Available from URL: http://www.usg.szkola.pl/ (in Polish). 
20. Gajewicz W. Ultrasonografia w praktyce lekarza rodzinnego. Diagnostyka wybranych narządów jamy brzusznej. Lek Rodz 2002; 7(9): 74-79 (in Polish).

21. Polskie Towarzystwo Ultrasonograficzne. Polish Ultrasound Society. Zasady uzyskiwania i przedłużania ważności certyfikatów PTU [cited: 21.11.2016]. Available from URL: http://www.usgptu.waw.pl/files/783824634/file/zasady_uzyskiwania_i_przedluzania_waznosci_certyfikatow_.pdf (in Polish).

22. Sekcja Ultrasonografii Polskiego Towarzystwa Ginekologicznego. Rodzaje i zasady uzyskania certyfikatów Sekcji USG PTG [cited: 23.11.2016]. Available from URL:http://www.usgptg.pl/index.php/component/content/article.html?id=1071\&itemid=69 (in Polish).

23. Polskie Towarzystwo Reumatologiczne. Rejestr certyfikatów USG PTR [cited: 23.11.2016]. Available from URL: http://www.reumatologia.ptr.net.pl/?rejestr-certyfikatow-usg-ptr,83 (in Polish).

24. Szwamel K, Polański P, Kurpas D. Experiences of family physicians after a CME ultrasound course. Fam Med Prim Care Rev 2017; 19(1): 62-69, doi: 10.5114/fmpcr.2017.66666.

25. Schumacher SM, Leone AF, Rao V, et al. Point of care ultrasound by primary care physicians and geriatricians: old adults, new technology, potential benefits and burdens. J Gerontol Geriat Res 2012; 1: 102, doi: 10.4172/2167-7182.1000102.

26. Ćwik G. Standards of the Polish Ultrasound Society - update. Pancreas examination. J Ultrason 2013; 13: 167-177.

27. Tshibwabwa ET, Groves HM. Integration of ultrasound in the education programme in anatomy. Med Educ 2005; 39(11): 1148.

28. Sutherland JE, Sutphin D, Redican K, et al. Telesonography: foundations and future directions. JUM 2011; 30: 517-522.

29. Kowalska K, Kalbarczyk WP. Koordynowana opieka zdrowotna. Doświadczenia międzynarodowe, propozycje dla Polski. Warszawa: Sprawne Państwo. Program EY; 2013: 92. Available from URL: http://www.ey.com/Publication/vwLUAssets/EY_Sprawne_Pa\%C5\%84stwo_Raport_Koordynowana_Opieka_Zdrowotna/\$FILE/EY_Sprawne_Panstwo_KOZ.pdf (in Polish).

30. Brisson $\mathrm{AM}$, Steinmetz $\mathrm{P}$, Oleskevich $\mathrm{S}$, et al. $\bar{A}$ comparison of telemedicine teaching to in-person teaching for the acquisition of an ultrasound skill - a pilot project. J Telemed Telecare 2015; 21(4): 235-239, doi: 10.1177/1357633X15575446.

31. Micks T, Smith A, Parsons M, et al. Point-of-care ultrasonography. Can J Rural Med 2016; 21(1): 28-29.

Tables: 2

Figures: 1

References: 31

Received: 29.03.2017

Revised: 08.05.2017

Accepted: 14.05 .2017

Address for correspondence:

Katarzyna Szwamel, MSc

Opole Medical School

ul. Katowicka 68

45-060 Opole

Polska

Tel.: +48 605 513-431

E-mail: k.szwamel@interia.pl 